\title{
ІСТОРИЧНІ ЕТАПИ РОЗВИТКУ УКРАЇНСЬКОЇ СИСТЕМИ НАДАННЯ АДМІНІСТРАТИВНИХ ПОСЛУГ НАСЕЛЕННЮ
}

\begin{abstract}
Стаття присвячена дослідженню історичних етапів розвитку української системи надання адміністративних послуг населенню. 3'ясовано, щзо в прочесі дослідження вітчизняних наукових літературних джерел можна помітити, щзо поняття «адміністративні послуги» протягом різних етапів свого розвитку виступали синонімом до управлінських, державних та муніципальних послуг. Однак, на даний час не лише науково, але й законодавчо закріплено саме поняття «адміністративні послуги». Встановлено, щьо розвиток адміністративних послуг в Украӥні можна поділити на 4 етапи: I eтаn (1998-2005 роки); II етап (2005-2009 роки); III етап (2009-2014 роки); IV етап (2014 до сьогодні). 3'ясовано, щзо найважливішою подією у розвитку вітчизняної системи розвитку адміністративних послуг стало прийняття у 2012 ройі Закону України «Про адміністративні послуги» № 5203-VI. Загалом, проводячи дослідження урядових ініціатив у сфері надання адміністративних послуг можна дійти висновку про неефективність простих та часткових відповідей на складні запитання. Тому варто реалізовувати системні заходи, спрямовані на реформування иілої системи публічних послуг загалом.

Ключові слова: адміністративні послуги, система надання адміністративних послуг населенню, етапи розвитку, ичентр надання адміністративних послуг, органи влади, місцеве самоврядування.
\end{abstract}

Н.О. СИДОРЕНКО

Институт подготовки кадров Государственной службы занятости Украины ORCID: 0000-0001-8734-9704

И.В. ШКУРАТ

Институт подготовки кадров Государственной службы занятости Украины ORCID: 0000-0002-8810-2890

\section{ИСТОРИЧЕСКИЕ ЭТАПЫ РАЗВИТИЯ УКРАИНСКОГО СИСТЕМЫ ПРЕДОСТАВЛЕНИЯ АДМИНИСТРАТИВНЫХ УСЛУГ НАСЕЛЕНИЮ}

\begin{abstract}
Статья посвящена исследованию исторических этапов развития украинской системы предоставления административных услуг населению. Установлено, что в процессе исследования отечественных научных литературных источников можно заметить, что понятие «административные услуги» в течение различных этапов своего развития выступали синонимом управленческих, государственных и муниципальных услуг. Однако, в настоящее время не только научно, но и законодательно закреплено само понятие «административные услуги». Установлено, что развитие административных услуг в Украине можно разделить на 4 этапа: I этап (1998-2005 годы) II этап (2005-2009 годы) III этап (2009-2014 годы) IV этапе (2014 по настоящее время). Установлено, что важнейшим событием в развитии отечественной системы развития административных услуг стало принятие в 2012 году Закона Украины «Об административных услугах» № 5203-VI. В общем, проводя исследования правительственных инициатив в сфере предоставления административных услуг можно сделать вывод о неэффективности простых и частных ответов на сложные вопросы. Поэтому стоит реализовывать системные меры, направленные на реформирование всей системы публичных услуг в ияелом.
\end{abstract}

Ключевые слова: административные услуги, система предоставления административных услуг населению, этапь развития, ичентр предоставления административных услуг, органь власти, местное самоуправление.

N.O. SYDORENKO

Institute of personnel training Ukrainian state employment service training institute ORCID: 0000-0001-8734-9704 


\section{HISTORICAL STAGES OF DEVELOPMENT OF THE UKRAINIAN SYSTEM OF PROVISION OF ADMINISTRATIVE SERVICES TO THE POPULATION}

The article is devoted to the study of the historical stages of development of the Ukrainian system of providing administrative services to the population. It was found that in the process of research of domestic scientific literature sources it can be noticed that the concept of "administrative services" during different stages of its development was synonymous with administrative, state and municipal services. However, at present, not only scientifically, but also legally, the very concept of "administrative services" is enshrined. It is established that the development of administrative services in Ukraine can be divided into 4 stages: I stage (1998-2005); Phase II (2005-2009); Stage III (2009-2014); Stage IV (2014 to date). It was found that the most important event in the development of the domestic system of administrative services was the adoption in 2012 of the Law of Ukraine "On Administrative Services" № 5203-VI. In general, a study of government initiatives in the field of administrative services suggests that simple and partial answers to complex questions are ineffective. Therefore, it is necessary to implement systemic measures aimed at reforming the entire system of public services in general.

Key words: administrative services, system of providing administrative services to the population, stages of development, center of providing administrative services, authorities, local self-government.

\section{Постановка проблеми}

Беручи до уваги той факт, що протягом останнього часу в Україні було розпочато адміністративну реформу, доволі гостро постала проблематика покращення якості надання адміністративних послуг, які надають органи публічної влади населенню. Варто зазначити, що розвиток української системи надання адміністративних послуг населенню триває вже досить багато років. Ї̈̈ розвиток можна поділити на певні етапи, пов'язаних із різноманітними пріоритетними напрямами роботи уряду. Через це, на сьогоднішній день досить важливо грунтовно дослідити питань появи та історичного розвитку української системи надання адміністративних послуг населенню.

Аналіз останніх досліджень і публікацій

Дослідженням еволюції розвитку адміністративних послуг в Україні займаються так і науковці як Д.Ю. Записний, Т. Маматова, А.І. Неділько, Т.О. Паутова та інші.

Формулювання мети дослідження

Мета статті полягає у проведенні дослідження історичних етапів розвитку української системи надання адміністративних послуг населенню.

\section{Викладення основного матеріалу дослідження}

Перш за все варто зауважити, що усі послуги, які надають населенню не лише державні та місцеві органи влади, але й установи та організації, які їм підпорядковуються, є сферою публічних послуг. У свою чергу, публічні послуги можуть бути як державними, так і муніципальними, важливим елементом яких виступають адміністративні послуги.

У процесі дослідження вітчизняних наукових літературних джерел можна помітити, що поняття «адміністративні послуги» протягом різних етапів свого розвитку виступали синонімом до управлінських, державних та муніципальних послуг. Однак, на даний час не лише науково, але й законодавчо закріплено саме поняття «адміністративні послуги». Водночас, якщо адміністративні послуги прирівнювати із публічними послугами, які мають місце в країнах $\mathrm{CC}$, то можна відмітити певні ïx розбіжності та суперечності, які потрібно вирішити в подальшому використанні цього поняття.

Протягом останніх років значна увага відводиться розробці та впровадженню інституційного та нормативно-правового забезпечення надання адміністративних послуг, а саме: відкриваються сучасні центри надання адміністративних послуг, впроваджено Єдиний державний портал адміністративних послуг, Концепція Державної цільової програми створення та функціонування інформаційної системи надання адміністративних послуг на період до 2017 року та інші. В той же час, механізм надання адміністративних послуг України потребує вдосконалення, що обумовлено його непрозорістю, нераціональністю та досить часто не врахуванням інтересів громадян [4].

В Україні розвиток адміністративних послуг і перехід від управлінських відносин між державою та народом в реалізацію принципу народовладдя - коли держава орієнтується на потреби народу, а державні службовці служать народові розпочався з 90-х років. Одним із документів, який заклав основи для формування сучасного механізму надання адміністративних послуг в Україні, стала Концепція адміністративної реформи, затверджена Указом Президента України у 1998 році. Метою реформи було «формування системи державного управління, яка стане близькою до потреб і запитів людей, а головним пріоритетом іiі діяльності буде служіння народові, національним інтересам», а одним із завдань для реалізації цієї мети було «запровадження нової ідеології функціонування виконавчої влади і місцевого самоврядування як діяльності щодо забезпечення реалізації прав і свобод громадян, надання державних та громадських послуг» [18]. 
Розвиток адміністративних послуг в Україні можна поділити на 4 етапи:

І етап (1998-2005 роки);

II етап (2005-2009 роки);

III етап (2009-2014 роки);

IV етап (2014 до сьогодні).

Для виконання Концепції № 810/98 було прийнято чимало законодавчих актів, які деталізують особливості надання публічних послуг. Так, у 2001 р. Президентом України Кучмою Л.Д. було ухвалено основні напрями конкурентної політики на 2002-2004 роки [22]. Головний напрям даної політики полягав в оптимізації повноважень органів публічної влади в Україні.

Крім цього, протягом даного етапу надання публічних послуг врегульовувалися постановами Кабінету Міністрів України «Про порядок використання коштів, отриманих органами державної влади від надання ними послуг відповідно до законодавства, та іiі розміри» від 25 червня 2001 p. № 702 [21] i «Про затвердження переліку груп власних надходжень бюджетних установ, вимог щодо їх утворення та напрямів використання» від 17 травня 2002 р. № 659 [12].

У 2004 р. було затверджено Програму розвитку державної служби на 2005-2010 роки [16]. Мета даної Програми полягала у визначенні та здійсненні певних заходів, які спрямовані на посилення ефективності роботи органів державної влади, а також на досягнення соціальних євростандартів в Україні. Усі зусилля державних органів були направлені на прозору роботу державної служби України.

Наступний етап розвитку адміністративних послуг в Україні припадає на 2005-2009 роки. Так, у 2005 р. було прийнято Закон України «Про дозвільну систему у сфері господарської діяльності» [10], який розкривав основні принципи функціонування дозвільної системи і встановлював систему роботи дозвільних органів, які видавали дозвільні документи. Даний Закон надав потужний поштовх створенню єдиних дозвільних центрів (ЄДЦ). Не зважаючи на те, що дана політика була покликана покращити умови для отримання публічних послуг тільки суб'єктами господарювання, в основному вона реалізовувалася відповідно із загальними положеннями створення універсамів послуг.

У 2006 p. Кабінет Міністрів України затвердив Концепцію розвитку системи надання адміністративних послуг органами виконавчої влади. Даний документ визначив принципи надання адміністративних послуг, а також заклав основи щодо платності адміністративних послуг, їх децентралізацію, систему мотивації працівників, які надають адміністративні послуги, стандарти надання адміністративних послуг. Крім того, були запроваджені критерії оцінки якості адміністративних послуг: результативність, своєчасність, територіальну наближеність адміністративного органу до отримувачів послуг та наявність транспортного сполучення, запровадження принципу «єдиного вікна», повага до особи, забезпечення побутових зручностей та ін. [14].

Таким чином, уряд визначив головні завдання своєї діяльності. Водночас найважливіше завдання в сфері надання адміністративних послуг полягає у максимальній їх децентралізації задля наближення до суспільства визначеної адміністративно-територіальної одиниці. Реалізація даного завдання передбачає передачу чи делегування належних функцій місцевим органам влади та іншим установам та організаціям. Інше чи не найголовніше завдання, передбачене Концепцією полягає у запровадженні найефективніших форм надання адміністративних послуг населенню, зокрема запровадження універсамів послуг (ЦНАПів) в якості організації надання найбільш розповсюджених адміністративних послуг в межах одного приміщення.

У 2007 р. було затверджено План заходів щодо реалізації Концепції розвитку системи надання адміністративних послуг органами виконавчої влади [14], який передбачав перегляд оплачуваних адміністративних послуг; розробку шаблонів послуг; законодавче врегулювання передачі функцій органів виконавчої влади місцевим органам; розроблення методики формування собівартості та 3 iі врахуванням перерахунок величини плати за надані послуги; запровадження автоматизації документообігу з надання публічних послуг із застосовуванням електронного цифрового підпису; подання на розгляд Уряду проекту Адміністративно-процедурного кодексу тощо.

Наступний етап розвитку публічних послуг в Україні припадає на 2009-2014 роки. Протягом 2009 року уряд країни приділяв чимало уваги платним державним послуг. Так, 25 лютого 2009 р. було видано Розпорядження Кабінету Міністрів України «Про заходи щодо упорядкування надання державних платних послуг» від 25.02.2009 p. № 251-р [20] та Постанову Кабінету Міністрів України «Деякі питання платних державних послуг» від 11 березня 2009 року № 234 [1]. Найважливіше завдання, передбачене даними нормативно-правовими документами, полягає не лише у перегляді переліку державних оплачуваних послуг задля скасування послуг, які дублюють одна одну та є безпідставно виділеними в окремі послуги, але й у підготовці реєстру державних оплачуваних послуг та законопроекту «Про адміністративні послуги». Таке рішення було прийнято в основному через щорічного недоотримання бюджетами різних рівнів значної суми коштів, оскільки більшість державних послуг надаються суб'єктами без статусу бюджетних інституцій, а оплата за надання подібних послуг надходить на фінансові рахунки приватних підприємців. Крім того, даним розпорядженням 
передбачається спрямування усіх грошових ресурсів за державні оплачувані послуги до державного бюджету, заборона передачі повноважень, пов'язаних із наданням державних оплачуваних послуг підприємствам, чим практично, знищив підприємства, які надавали державні платні послуги. Варто зауважити, що головною вимогою уряду є перегляд величини плати за надання послуг і узгодити iï iз найменшими затратами, які потрібні для їх надання. 3 однієї сторони, це передбачає зниження величини оплати за надання окремих адміністративних послуг, оскільки їх вартість є завищеною. 3 іншої сторони, при реалізації не популістської політики стосовно більшості адміністративних послуг це повинно б збільшити величину плати, оскільки на даний час левова частка адміністративних послуг надається по нижчій відносно собівартості вартості.

У 2009 р. Президент України Ющенко В.А. видав Указ «Про заходи із забезпечення додержання прав фізичних та юридичних осіб щодо одержання адміністративних (державних) послуг» від 3 липня 2009 року № 508 [17]. Даний Указ мав на меті поліпшити умови виконання конституційних прав на здійснення підприємницької діяльності, забезпечення належного функціонування дозвільної системи в сфері господарської діяльності, забезпечення захисту появи корупції при наданні публічних послуг.

Разом з тим, слід наголосити, що Головним управлінням державної служби України у 2009 році було ініційовано утворення реєстру адміністративних послуг. Так, Постановою Кабінету Міністрів України від 27 квітня 2009 року № 532 було затверджено Положення про Реєстр державних та адміністративних послуг. Передбачалося, що Реєстр буде єдиною комп'ютерною базою даних про державні та адміністративні послуги, які надаються органами виконавчої влади, державними підприємствами, установами та організаціями, а також органами місцевого самоврядування у процесі виконання ними делегованих державою повноважень. У 2010 році до зазначеного Положення були внесені зміни насамперед термінологічного характеру. Протягом тривалого часу згаданий реєстр адміністративних послуг був доступний у тестовому режимі і дозволяв здійснювати пошук інформації за суб'єктами надання послуги (за органами виконавчої влади), за сферами, а також за видом (назвою) послуги. Реєстр містить інформацію про нормативне регулювання адміністративної послуги, суб'єкта їі надання та розмір плати. Щоправда, питання про зручність користування Реєстром, його повноту, коректність, а також практичну цінність ще залишаються відкритими[2].

У цьому ж році було ухвалено_Постанову Кабінету Міністрів України «Деякі питання надання державних платних (адміністративних) послуг, видачі документів дозвільного характеру (переліки платних послуг та перелік документів, видача яких не передбачена законом)», якою передбачалася: заборона у законодавчо передбачених випадках віддати повноваження усім підприємства, крім державн ої форми власності; справляння плати у відсотках до вартості об’ єкта згідно кошторису тощо.

Підсумковим нормативно-правовим актом 2009 року $є$ Постанова «Про заходи щодо упорядкування державних, у тому числі адміністративних послуг» від 17 липня 2009 року № 737, яка затверджувала Тимчасовий порядок надання державних, у тому числі адміністративних послуг [19]. Даний порядок визначав порядок надання державних послуг органів публічного управління в межах наданих їм повноважень.

Важливе значення у формуванні механізму надання адміністративних послуг мала Постанова Кабінету Міністрів України «Про затвердження Методики визначення собівартості платних адміністративних послуг». Цією постановою затверджено поняття собівартості адміністративної послуги - виражені в грошовій формі витрати адміністративного органу, безпосередньо пов'язані 3 наданням адміністративної послуги, а також складові та методику її обчислення [11].

Протягом 2010 р. було внесено чимало змін, зокрема до Положення про Реєстр державних та адміністративних послуг, Тимчасового порядку надання державних, у тому числі адміністративних послуг, а також до Закону України «Про дозвільну систему у сфері господарської діяльності». Протягом тривалого часу точилося чимало дискусій стосовно необхідності прийняття Закону України «Про адміністративні послуги», який би забезпечував виконання різного роду заходів щодо розвитку вітчизняної системи надання адміністративних послуг. Ухвалення такого Закону у 2012 році [6] стало основою в подальшому розвитку даної системи, оскільки визначив правові засади реалізації прав, свобод і законних інтересів фізичних та юридичних осіб у сфері надання адміністративних послуг.

Позитивними сторонами даного Закону № 5203-VI слід вважати визначення головних обов’язків як органів місцевої влади, так і районних держадміністрацій в частині створення центрів надання адміністративних послуг (ЦНАП); заборону вимагання документації чи інших інформаційних даних, якими володіють суб'єкти надання таких послуг; запровадження стандартизованого терміну «адміністративний збір», під яким варто розуміти єдину плату за платні адміністративні послуги тощо. Своєю чергою серед головних недоліків вище зазначеного Закону № 5203-VI варто відмітити недосконале визначення переліку суб'єктів, які надають адміністративні послуги. Крім цього, зважаючи на те, що в якості максимальної величини плати за надання адміністративної послуги, тобто величини адміністративного збору наведено невияснений критерій «соціально-економічного значення», в Законі №5203-VI не визначено «верхній поріг» для обчислення плати за надання послуги. 
1 серпня 2013 р. Кабінет Міністрів України Постановою № 588 затвердив Примірний регламент центру надання адміністративних послуг, який визначає порядок організації роботи центру надання адміністративних послуг, його територіальних підрозділів, віддалених робочих місць адміністраторів, порядок дій адміністраторів центру та їх взаємодії із суб'єктами надання адміністративних послуг [15].

Розглядаючи нормативні акти, які регламентують надання адміністративних послуг в Україні не можемо оминути Концепцію Державної цільової програми створення та функціонування інформаційної системи надання адміністративних послуг на період до 2017 року. Метою Програми є створення доступних і зручних умов для реалізації та захисту прав, свобод і законних інтересів фізичних та юридичних осіб, підвищення якості надання адміністративних послуг шляхом здійснення заходів із створення та функціонування системи електронної міжвідомчої взаємодії державних органів, Єдиного державного порталу адміністративних послуг, цілодобової Урядової телефонної довідки про адміністративні послуги [23].На нашу думку найбільш суттєвий недолік вище зазначеної Концепції Державної цільової програми полягає у відсутності конкретних часових періодів реалізації передбачених нею заходів, а також у чіткому визначенні відповідальних виконувачів тощо.

Новітнім етапом в розвитку системи адміністративних послуг є період 32014 року до сьогоднішнього дня. Даний етап розпочався із прийняття Концепції реформування місцевого самоврядування та територіальної організації влади в Україні (1 квітня 2014 року) [24], мета якої полягала у визначенні напрямків, механізмів та термінів формування результативного місцевого самоврядування для сприяння повноцінному життєвому середовищу для населення, наданні якісних i загальнодоступних публічних послуг, задоволенні суспільних потреб, а також узгодженні державних інтересів з територіальними громадами.

У грудні 2015 року Верховною Радою України ухвалено Закон України «Про внесення змін до деяких законодавчих актів України щодо розширення повноважень органів місцевого самоврядування та оптимізації надання адміністративних послуг». Цей законодавчий акт розроблено в рамках виконання пункту 2.3.1 Коаліційної угоди, яким передбачено делегувати органам місцевого самоврядування відповідного рівня повноваження з надання базових адміністративних послуг. Завданням реформи у цій сфері $є$ надання публічних послуг відповідно до державних стандартів 3 урахуванням необхідності забезпечення територіальної доступності, що передбачає надання послуг на території громади, де проживає особа[2].

Нові нормативно-правові акти у сфері надання адміністративних послуг, які були прийняті у 2016 р., мали на меті забезпечити відкритість та відповідну якість адміністративних послуг за рахунок розподілу повноважень між державними та місцевими органами влади відповідно до принципів децентралізації, та модернізація процедур та передумов надання адміністративних послуг. Новий закон зобов'язав місцеві органи влади та місцеві державні адміністрації надавати населенню найбільш популярні адміністративні послуги. Так, органам місцевого самоврядування (виконавчому органу сільської, селищної або міської ради, сільському голові (у випадку, коли відповідно до закону виконавчий орган сільської ради не утворено) надано повноваження щодо реєстрації місця проживання та зняття з реєстрації місця проживання особи, ведення відповідного реєстру територіальної громади, що в результаті позбавить жителів необхідності збирати відповідні довідки про склад сім’ї та проживання, необхідні при наданні соціальних та інших послуг[2].

У 2017 році Кабінетом Міністрів України було схвалено зміни до Закону України «Про адміністративні послуги», пов'язані із покращенням процесу надання адміністративних послуг населенню і з'ясуванням певних аспектів формування і організації діяльності ЦНАПів. Ініціатором таких змін до Закону України «Про адміністративні послуги» було Міністерство економічного розвитку і торгівлі України. Відтак, для того, щоб одержати певні дозвільні документи потрібно тільки відправити звернення до відповідного ЦНАПу. Заявник може бути відсутнім на погоджувальних процедурах. При умові, коли немає заперечень погоджувальних інституцій впродовж 10-ти днів послугу можна вважати наданою.

Підтвердженням напрямів подальшого розвитку сфери надання публічних послуг у контексті Концепції функціонування сервісної держави (держави для громадян й бізнесу, забезпечення належної реалізації прав фізичних та юридичних осіб у сфері надання публічних, у тому числі адміністративних, послуг, створення сучасної інфраструктури, зручних та доступних електронних сервісів) виступає й Указ Президента України «Про деякі заходи із забезпечення надання якісних публічних послуг» від 04.09.2019 p. № 647/2019[9].

Підсилюють цей напрям подальшого розвитку сфери публічних послуг та створюють відповідне підгрунтя для подальших законодавчих змін було затверджено у 2019-2020 роках низку нормативних документів у напрямі діджиталізації даної сфери. Серед яких можна виділити Розпорядження КМУ від 30.01.2019 р. № 37-р «Про затвердження плану заходів щодо реалізації Концепції розвитку системи електронних послуг в Україні на 2019-2020 роки»[13]. Виконання даної Концепції дасть можливість 
покращити якість надання адміністративних послуг як для фізичних, так і юридичних осіб згідно із вимогами СС.

Напрям подальшої діджиталізації сфери надання адміністративних послуг також підсилюють норми двох постанов Кабінету Міністрів України: «Питання Єдиного державного веб-порталу електронних послуг та Єдиного державного порталу адміністративних послуг» від 04.12.2019 р. № 1137 [5] та «Про внесення змін до деяких актів Кабінету Міністрів України з питань діяльності Міністерства цифрової трансформації» від 05.02.2020р. № 123[7]. Саме ці акти містять норми, що визначають мету, основні завдання, функціональні можливості та суб'єктів Єдиного державного веб-порталу електронних послуг «Портал Дія», зміст інформації на ньому та порядок їі внесення, а також інші питання функціонування зазначеного веб-порталу та інших електронних сервісів держави[3].

3 листопада 2020 р. прийнято Закон України № 943-IX «Про внесення змін до деяких законодавчих актів України щодо оптимізації мережі та функціонування центрів надання адміністративних послуг та удосконалення доступу до адміністративних послуг, які надаються в електронній формі»[8], за яким у ЦНАП об'єднаної територіальної громади надаватимуться усі адміністративні та інші публічні послуги органів місцевого самоврядування, територіальних органів центральних органів виконавчої влади, а також адміністративні послуги за договорами щодо обслуговування у ЦНАП жителів інших територіальних громад. Даним законом передбачено поетапне утворення ЦНАП органів місцевого самоврядування протягом 3 років у кожній з новостворених громад. ЦНАП органів місцевого самоврядування обов'язково будуть утворюватися в усіх населених пунктах 3 чисельністю населення більше однієї тисяч, старостам будуть надані окремі функції адміністратора[3].

Ми вважаємо, що нормативно-правова база, яка регулює надання адміністративних послуг в Україні найближчим часом буде удосконалюватися. Делеговані повноваження ОТГ з року в рік будуть збільшуватися, що дозволить створити сприятливі умови задля безперервного удосконалення діяльності ЦНАП територіальних громад відповідно до чинної нормативно-правової бази. На даний час найважливішим напрямком удосконалення публічної служби і подальшого реформування в сфері надання адміністративних послуг в Україні є покращення якості надання таких послуг, наприклад за рахунок підвищення кваліфікації і створення сприятливих передумов для постійного професійного навчання публічних службовців, а також популяризація кращого вітчизняного та іноземного досвіду стосовно особливостей надання адміністративних послуг.

\section{Висновки}

На основі вище наведеного можна дійти висновку, що процес формування української системи надання адміністративних послуг бере початок з 1998 року, проте найактивніший їі розвито припадає саме на 2005 рік. Саме у 2005 р. було прийнято Закон України «Про дозвільну систему у сфері господарської діяльності», відповідно до якого почали створюватися єдині дозвільні центри. Найважливішою подією у розвитку вітчизняної системи розвитку адміністративних послуг стало прийняття у 2012 році Закону України «Про адміністративні послуги» № 5203-VI. Загалом нами визначено 4 етапи розвитку адміністративних послуг в Україні, останній з яких розпочався у 2014 році, що пов'язано із реформуванням системи місцевого самоврядування. Нові нормативно-правові акти у сфері надання адміністративних послуг, які були прийняті у 2016 р., мали на меті забезпечити відкритість та відповідну якість адміністративних послуг за рахунок розподілу повноважень між державними та місцевими органами влади відповідно до принципів децентралізації, та модернізація процедур та передумов надання адміністративних послуг. Новий закон зобов'язав місцеві органи влади та місцеві державні адміністрації надавати населенню найбільш популярні адміністративні послуги. Загалом, проводячи дослідження урядових ініціатив у сфері надання адміністративних послуг можна дійти висновку про неефективність простих та часткових відповідей на складні запитання. Тому варто реалізовувати системні заходи, спрямовані на реформування цілої системи публічних послуг загалом. Задля цього, на нашу думку, доцільно виконати наступні заходи. Так, варто відійти від надання послуг владними органами і не сприяти недобросовісній конкурентній боротьбі зі сторони публічної сфери приватним організаціям. У той же час, варто звернути увагу на те, що найважливіше значення має відігравати рівень якості надання адміністративних послуг, а не можливість наповнення за їх рахунок державного бюджету, оскільки головне завдання держави полягає у служінні своєму народу.

\section{Список використаної літератури}

1. Деякі питання платних державних послуг: Постанова Кабінету Міністрів України від 11.03.2009 p. № 234. URL: http://zakon2.rada.gov.ua/laws/show/234-2009-\%D0\%BF.

2. Записний Д.Ю. Історія становлення та розвитку системи надання адміністративних послуг в Україні. Аспекти публічного управління. 2016. № 8 (34). С. 16-24.

3. Маматова Т. Система надання адміністративних послуг в Україні: особливості нормативноправового регулювання. Аспекти публічного управління. 2020. № 6. С. 164-177.
4. Паутова
Т.О., Неділько
A.I. Формування
та удосконалення
системи
надання 
адміністративних послуг в Україні. Державне управління: удосконалення та розвиток. 2017. № 5. URL: http://www.dy.nayka.com.ua/?op=1\&z=1081.

5. Питання Єдиного державного веб-порталу електронних послуг та Єдиного державного порталу адміністративних послуг: постанова Кабінету Міністрів України від 04.12.2019 р. № 1137. URL:https://www.kmu.gov.ua/npas/pitannya-yedinogo-derzhavnogo-veb-portalu-elektronnih-poslug-tayedinogo-derzhavnogo-portalu-administrativnih-poslug-i041219.

6. Про адміністративні послуги: Закон України від 06.09.2012 p. № 5203-17. URL: https://zakon.rada.gov.ua/laws/show/5203-17\#Text.

7. Про внесення змін до деяких актів Кабінету Міністрів України з питань діяльності Міністерства цифрової трансформації: Постанова Кабінету Міністрів України від 05.02.2020 p. № 123 . URL: https://zakon.rada.gov.ua/laws/show/123-2020-\%D0\%BF.

8. Про внесення змін до деяких законодавчих актів України щодо оптимізації мережі та функціонування центрів надання адміністративних послуг та удосконалення доступу до адміністративних послуг, які надаються в електронній формі: Закон України від 03.11.2020р. № 943-IX. URL: https://zakon.rada.gov.ua/laws/show/943-20\#Text.

9. Про деякі заходи із забезпечення надання якісних публічних послуг: Указ Президента України від 04.09.2019 р. № 647/2019. URL: https://zakon.rada.gov.ua/laws/show/647/2019\#Text.

10. Про дозвільну систему у сфері господарської діяльності: Закон України від 06.09.2005 p. № 48. URL:https://zakon.rada.gov.ua/laws/show/2806-15\#Text.

11. Про затвердження Методики визначення собівартості платних адміністративних послуг: Постанова Кабінету Міністрів України від 27.01.2010 p. № 66 . URL: http://zakon4.rada.gov.ua/laws/show/66-2010-\%D0\%BF.

12. Про затвердження переліку груп власних надходжень бюджетних установ, вимог щодо їх утворення та напрямів використання: Постанова Кабінету Міністрів України від 17.05.2002 p. № 659 . URL: http://zakon4.rada.gov.ua/laws/show/659-2002-п.

13. Про затвердження плану заходів щодо реалізації Концепції розвитку системи електронних послуг в Україні на 2019-2020 роки: Розпорядження КМУ від 30.01.2019 p. № 37-p. URL:https://www.kmu.gov.ua/npas/proalizaciyi-koncepciyi-rozvitku-sistemi-elektronnih-poslug-v-ukrayini-na20192020-roki.

14. Про затвердження плану заходів щодо реалізації Концепції розвитку системи надання адміністративних послуг органами виконавчої влади: Розпорядження Кабінету Міністрів України від 27.06.2007 p. № 494-p. URL: http://zakon3.rada.gov.ua/laws/show/494-2007-\%D1\%80.

15. Про затвердження Примірного регламенту центру надання адміністративних послуг: $\begin{array}{lllllllll}\text { Постанова } & \text { Кабінету Міністрів } & \text { України від } & 01.08 .2013 & \text { p. } & \text { № } & 588 \text {. URL: }\end{array}$ https://zakon.rada.gov.ua/laws/show/588-2013-\%D0\%BF\#Text.

16. Про затвердження Програми розвитку державної служби на 2005-2010 роки: Постанова Кабінету Міністрів України від 8.06.2004 p. № 746. URL: http://zakon4.rada.gov.ua/laws/show/746-2004-п.

17. Про заходи із забезпечення додержання прав фізичних та юридичних осіб щодо одержання адміністративних (державних) послуг: Указ Президента України від 03.07.2009 р. № 508/2009. URL: http://zakon5.rada.gov.ua/laws/show/508/2009.

18. Про заходи щодо впровадження Концепції адміністративної реформи в Україні : Указ Президента України від 22.07.1998 p. № 810/98. URL: http://zakon2.rada.gov.ua/laws/show/810/98.

19. Про заходи щодо упорядкування державних, у тому числі адміністративних послуг: Постанова Кабінету Міністрів України від 17.07.2009 p. № 737 . URL: http://zakon3.rada.gov.ua/laws/show/737-2009-\%D0\%BF.

20. Про заходи щодо упорядкування надання державних платних послуг: Розпорядження Кабінету Міністрів України від 25.02.2009 p. № 251-p. URL: http://zakon0.rada.gov.ua/laws/show/251-2009$\% \mathrm{D} 1 \% 80$.

21. Про порядок використання коштів, отриманих органами державної влади від надання ними послуг відповідно до законодавства, та іï розміри: Постанова Кабінету Міністрів України від 25.06.2001 p. № 702. URL: http://zakon4.rada.gov.ua/laws/show/702-2001-п.

22. Про Основні напрями конкурентної політики на 2002-2004 роки: Указ Президента України від 19.11.2001 p. № 1097/2001 URL: http://zakon4.rada.gov.ua/laws/show/1097/2001.

23. Про схвалення Концепції Державної цільової програми створення та функціонування інформаційної системи надання адміністративних послуг на період до 2017 року: Розпорядження Кабінету Міністрів України від 24.07.2013p. № 614-p. URL: https://zakon.rada.gov.ua/laws/show/614-2013\%D1\%80\#Text.

24. Про схвалення Концепції реформування місцевого самоврядування та територіальної організації влади в Україні: Розпорядження Кабінету Міністрів України від 01.04.2014 р. № 333. URL: http://zakon3.rada.gov.ua/laws/show/333-2014-\%D1\%80. 
25. Про схвалення Концепції розвитку системи надання адміністративних послуг органами виконавчої влади: Розпорядження Кабінету Міністрів України від 15.02.2006 p. № 90-р. URL:http://zakon5.rada.gov.ua/laws/show/90-2006-\%D1\%80.

\section{References}

1. Deiaki pytannia platnykh derzhavnykh posluh: Postanova Kabinetu Ministriv Ukrainy vid 11.03.2009 r. № 234 (Some issues of paid public services: Resolution of the Cabinet of Ministers of Ukraine). Available at: http://zakon2.rada.gov.ua/laws/show/234-2009-\%D0\%BF (accessed 13 July 2021).

2. Zapysnyi D.Iu. Istoriia stanovlennia ta rozvytku systemy nadannia administratyvnykh posluh $\mathrm{v}$ Ukraini [History of formation and development of the system of providing administrative services in Ukraine]. Aspekty publichnoho upravlinnia [Aspects of public administration], 2016, no. 8 (34), pp. 16-24.

3. Mamatova T. Systema nadannia administratyvnykh posluh v Ukraini: osoblyvosti normatyvnopravovoho rehuliuvannia [The system of administrative services in Ukraine: features of legal regulation]. Aspekty publichnoho upravlinnia [Aspects of public administration], 2020, no. 6, pp. 164-177.

4. Pautova T.O., Nedilko A.I. Formuvannia ta udoskonalennia systemy nadannia administratyvnykh posluh v Ukraini [Formation and improvement of the system of providing administrative services in Ukraine]. Derzhavne upravlinnia: udoskonalennia ta rozvytok [Public administration: improvement and development], 2017, no. 5. Available at: http://www.dy.nayka.com.ua/?op=1\&z=1081 (accessed 3 July 2021).

5. Pytannia Yedynoho derzhavnoho veb-portalu elektronnykh posluh ta Yedynoho derzhavnoho portalu administratyvnykh posluh: postanova Kabinetu Ministriv Ukrainy vid 04.12.2019 r. № 1137 (Issues of the Unified State Web Portal of Electronic Services and the Unified State Portal of Administrative Services: Resolution of the Cabinet of Ministers of Ukraine). Available at: https://www.kmu.gov.ua/npas/pitannyayedinogo-derzhavnogo-veb-portalu-elektronnih-poslug-ta-yedinogo-derzhavnogo-portalu-administrativnihposlug-i041219 (accessed 3 July 2021).

6. Pro administratyvni posluhy: Zakonu Ukrainy vid 06.09.2012 r. № 5203-17 (On administrative services: Law of Ukraine). Available at: https://zakon.rada.gov.ua/laws/show/5203-17\#Text (accessed 4 July 2021).

7. Pro vnesennia zmin do deiakykh aktiv Kabinetu Ministriv Ukrainy z pytan diialnosti Ministerstva tsyfrovoi transformatsii: Postanova Kabinetu Ministriv Ukrainy vid 05.02.2020 r. № 123 (On amendments to some acts of the Cabinet of Ministers of Ukraine on the activities of the Ministry of Digital Transformation: Resolution of the Cabinet of Ministers of Ukraine). Available at: https://zakon.rada.gov.ua/laws/show/123-2020$\% \mathrm{D} 0 \% \mathrm{BF}$ (accessed 4 July 2021).

8. Pro vnesennia zmin do deiakykh zakonodavchykh aktiv Ukrainy shchodo optymizatsii merezhi ta funktsionuvannia tsentriv nadannia administratyvnykh posluh ta udoskonalennia dostupu do administratyvnykh posluh, yaki nadaiutsia v elektronnii formi: Zakon Ukrainy vid 03.11.2020 r. № 943-IX (On Amendments to Certain Legislative Acts of Ukraine Concerning the Optimization of the Network and Functioning of Centers for Provision of Administrative Services and Improvement of Access to Administrative Services Provided in Electronic Form: Law of Ukraine). Available at: https://zakon.rada.gov.ua/laws/show/943-20\#Text (accessed 6 July 2021).

9. Pro deiaki zakhody iz zabezpechennia nadannia yakisnykh publichnykh posluh: Ukaz Prezydenta Ukrainy vid 04.09.2019 r. № 647/2019 (On some measures to ensure the provision of quality public services: Decree of the President of Ukraine). Available at: https://zakon.rada.gov.ua/laws/show/647/2019\#Text(accessed 10 July 2021).

10. Pro dozvilnu systemu u sferi hospodarskoi diialnosti: Zakon Ukrainy vid 06.09.2005 r. № 48 (On the permit system in the sphere of economic activity: Law of Ukraine). Available at: https://zakon.rada.gov.ua/laws/show/2806-15\#Text (accessed 10 July 2021).

11. Pro zatverdzhennia Metodyky vyznachennia sobivartosti platnykh administratyvnykh posluh: Postanova Kabinetu Ministriv Ukrainy vid 27.01.2010 r. № 66 (On approval of the Methodology for determining the cost of paid administrative services: Resolution of the Cabinet of Ministers of Ukraine). Available at: http://zakon4.rada.gov.ua/laws/show/66-2010-\%D0\%BF (accessed 12 July 2021).

12. Pro zatverdzhennia pereliku hrup vlasnykh nadkhodzhen biudzhetnykh ustanov, vymoh shchodo yikh utvorennia ta napriamiv vykorystannia: Postanova Kabinetu Ministriv Ukrainy vid 17.05.2002 r. № 659 (On approval of the list of groups of own revenues of budgetary institutions, requirements for their formation and directions of use: Resolution of the Cabinet of Ministers of Ukraine). Available at: http://zakon4.rada.gov.ua/laws/show/659-2002-p(accessed 12 July 2021).

13. Pro zatverdzhennia planu zakhodiv shchodo realizatsii Kontseptsii rozvytku systemy elektronnykh posluh v Ukraini na 2019-2020 roky: Rozporiadzhennia KMU vid 30.01.2019 r. № 37-r. (On approval of the action plan for the implementation of the Concept of development of the electronic services system in Ukraine for 2019-2020: Order of the Cabinet of Ministers). Available at: https://www.kmu.gov.ua/npas/proalizaciyikoncepciyi-rozvitku-sistemi-elektronnih-poslug-v-ukrayini-na-20192020-roki (accessed 9 July 2021). 
14. Pro zatverdzhennia planu zakhodiv shchodo realizatsii Kontseptsii rozvytku systemy nadannia administratyvnykh posluh orhanamy vykonavchoi vlady: Rozporiadzhennia Kabinetu Ministriv Ukrainy vid 27.06.2007 r. № 494-r. (On approval of the action plan for the implementation of the Concept for the development of the system of providing administrative services by the executive authorities: Order of the Cabinet of Ministers of Ukraine). Available at: http://zakon3.rada.gov.ua/laws/show/494-2007-\%D1\%80 (accessed 9 July 2021).

15. Pro zatverdzhennia Prymirnoho rehlamentu tsentru nadannia administratyvnykh posluh: Postanova Kabinetu Ministriv Ukrainy vid 01.08.2013 r. № 588 (On approval of the Model Regulations of the Center for Provision of Administrative Services: Resolution of the Cabinet of Ministers of Ukraine). Available at: https://zakon.rada.gov.ua/laws/show/588-2013-\%D0\%BF\#Text (accessed 9 July 2021).

16. Pro zatverdzhennia Prohramy rozvytku derzhavnoi sluzhby na 2005-2010 roky: Postanova Kabinetu Ministriv Ukrainy vid 8.06.2004 r. № 746 (On approval of the Civil Service Development Program for 2005-2010: Resolution of the Cabinet of Ministers of Ukraine). Available at: http://zakon4.rada.gov.ua/laws/show/746-2004-p (accessed 15 July 2021).

17. Pro zakhody iz zabezpechennia doderzhannia prav fizychnykh ta yurydychnykh osib shchodo oderzhannia administratyvnykh (derzhavnykh) posluh: Ukaz Prezydenta Ukrainy vid 03.07.2009 r. № 508/2009 (On measures to ensure compliance with the rights of individuals and legal entities to receive administrative (state) services: Decree of the President of Ukraine). Available at: http://zakon5.rada.gov.ua/laws/show/508/2009 (accessed 15 July 2021).

18. Pro zakhody shchodo vprovadzhennia Kontseptsii administratyvnoi reformy v Ukraini : Ukaz Prezydenta Ukrainy vid 22.07.1998 r. № 810/98 (On measures to implement the Concept of Administrative Reform in Ukraine: Decree of the President of Ukraine). Available at: http://zakon2.rada.gov.ua/laws/show/810/98 (accessed 15 July 2021).

19. Pro zakhody shchodo uporiadkuvannia derzhavnykh, u tomu chysli administratyvnykh posluh: Postanova Kabinetu Ministriv Ukrainy vid 17.07.2009 r. № 737 (On measures to streamline public services, including administrative services: Resolution of the Cabinet of Ministers of Ukraine). Available at: http://zakon3.rada.gov.ua/laws/show/737-2009-\%D0\%BF (accessed 17 July 2021).

20. Pro zakhody shchodo uporiadkuvannia nadannia derzhavnykh platnykh posluh: Rozporiadzhennia Kabinetu Ministriv Ukrainy vid 25.02.2009 r. № 251-r. (On measures to regulate the provision of state paid services: Order of the Cabinet of Ministers of Ukraine). Available at: http://zakon0.rada.gov.ua/laws/show/2512009-\%D1\%80 (accessed 17 July 2021).

21. Pro poriadok vykorystannia koshtiv, otrymanykh orhanamy derzhavnoi vlady vid nadannia nymy posluh vidpovidno do zakonodavstva, ta yii rozmiry: Postanova Kabinetu Ministriv Ukrainy vid 25.06.2001 r. № 702 (On the procedure for the use of funds received by public authorities from the provision of services by them in accordance with the law, and its amounts: Resolution of the Cabinet of Ministers of Ukraine). Available at: http://zakon4.rada.gov.ua/laws/show/702-2001-p (accessed 16 July 2021).

22. Pro Osnovni napriamy konkurentnoi polityky na 2002-2004 roky: Ukaz Prezydenta Ukrainy vid 19.11.2001 r. № 1097/2001 (On the Main Directions of Competition Policy for 2002-2004: Decree of the President of Ukraine). Available at: http://zakon4.rada.gov.ua/laws/show/1097/2001 (accessed 13 July 2021).

23. Pro skhvalennia Kontseptsii Derzhavnoi tsilovoi prohramy stvorennia ta funktsionuvannia informatsiinoi systemy nadannia administratyvnykh posluh na period do 2017 roku: Rozporiadzhennia Kabinetu Ministriv Ukrainy vid 24.07.2013r. № 614-r. (On approval of the Concept of the State target program of creation and functioning of the information system of rendering of administrative services for the period till 2017: the Order of the Cabinet of Ministers of Ukraine). Available at: https://zakon.rada.gov.ua/laws/show/614-2013$\%$ D1\%80\#Text (accessed 18 July 2021).

24. Pro skhvalennia Kontseptsii reformuvannia mistsevoho samovriaduvannia ta terytorialnoi orhanizatsii vlady v Ukraini: Rozporiadzhennia Kabinetu Ministriv Ukrainy vid 01.04.2014 r. № 333 (On approval of the Concept of reforming local self-government and territorial organization of power in Ukraine: Order of the Cabinet of Ministers of Ukraine). Available at: http://zakon3.rada.gov.ua/laws/show/333-2014$\%$ D1\%80 (accessed 18 July 2021).

25. Pro skhvalennia Kontseptsii rozvytku systemy nadannia administratyvnykh posluh orhanamy vykonavchoi vlady: Rozporiadzhennia Kabinetu Ministriv Ukrainy vid 15.02.2006 r. № 90-r. (On approval of the Concept of development of the system of providing administrative services by executive authorities: Order of the Cabinet of Ministers of Ukraine). Available at: http://zakon5.rada.gov.ua/laws/show/90-2006-\%D1\%80 (accessed 18 July 2021). 